\title{
SCAPS Investigation of Chlorinated \\ Volatile Organic Compounds \\ in Groundwater at Building 525, \\ Aberdeen Proving Ground, Maryland
}

by William M. Davis, Jeff F. Powell,

S. Paul Miller, Stanley M. Swartzel

Approved For Public Release; Distribution Is Unlimited

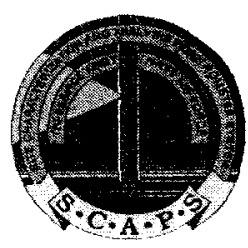


The contents of this report are not to be used for advertising, publication, or promotional purposes. Citation of trade names does not constitute an official endorsement or approval of the use of such commercial products.

The findings of this report are not to be construed as an official Department of the Army position, unless so designated by other authorized documents. 


\section{SCAPS Investigation of Chlorinated \\ Volatile Organic Compounds \\ in Groundwater at Building 525, \\ Aberdeen Proving Ground, Maryland}

by William M. Davis, Jeff F. Powell,

S. Paul Miller, Stanley M. Swartzel

U.S. Army Corps of Engineers

Waterways Experiment Station

3909 Halls Ferry Road

Vicksburg, MS 39180-6199

Final report

Approved for public release; distribution is unlimited 


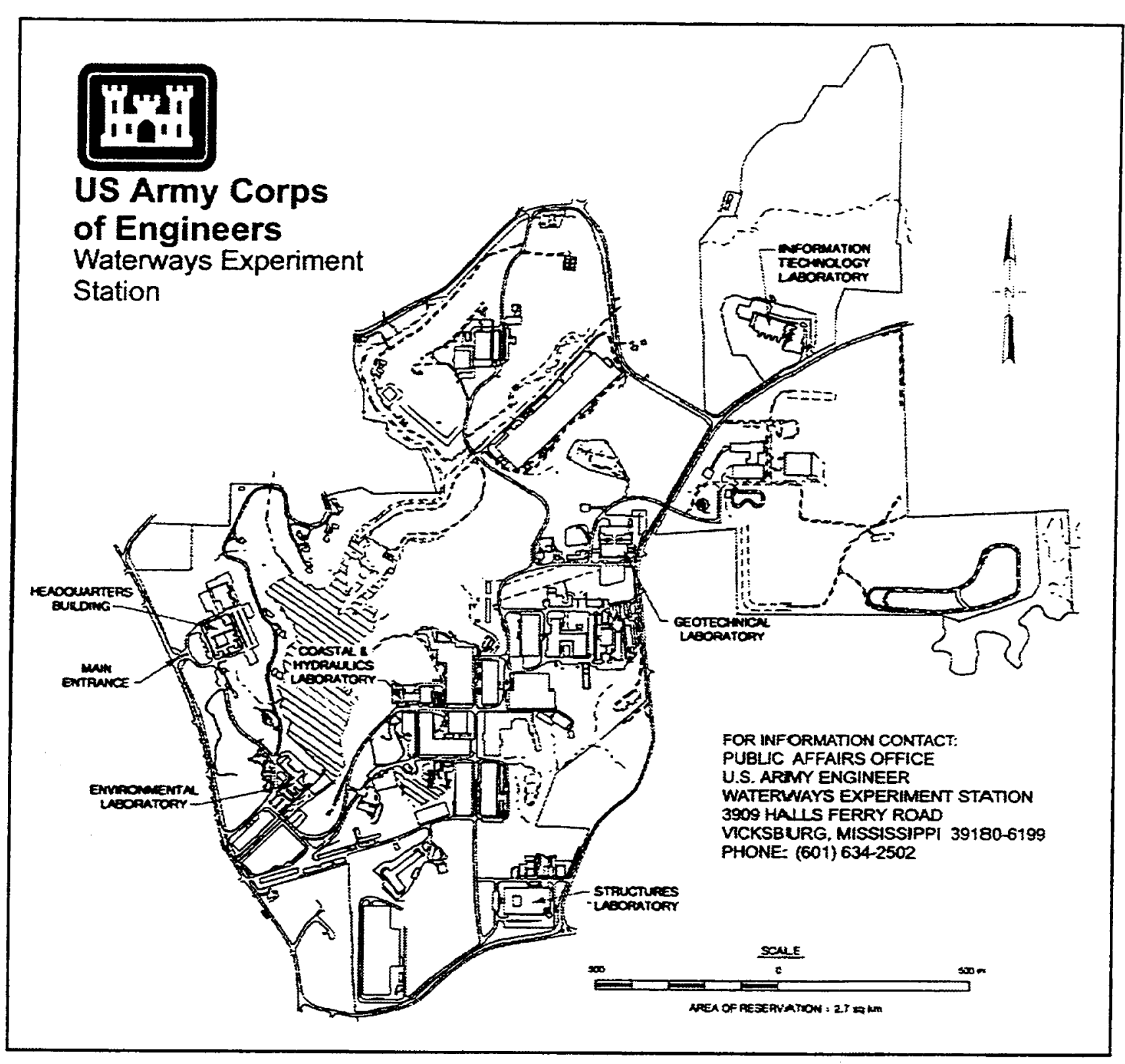

Waterways Experiment Station Cataloging-in-Publication Data

SCAPS investigation of chlorinated volatile organic compounds in groundwater at Building 525 , Aberdeen Proving Ground, Maryland / by William M. Davis ... [et. al] ; prepared for U.S. Army Corps of Engineers.

36 p. : ill. ; $28 \mathrm{~cm}$. - (Technical report ; EL-97-18)

Includes bibliographical references.

1. Penetrometer. 2. Groundwater - Environmental aspects -- Testing. 3. Organochlorine compounds - Environmental aspects. 4. Aberdeen Proving Ground (Md.) I. Davis, William M. II. United States. Army. Corps of Engineers. MI. U.S. Army Engineer Waterways Experiment Station. IV. Environmental Laboratory (U.S. Army Engineer Waterways Experiment Station) V. Tri-Service Site Characterization and Analysis Penetrometer System Program. VI. Series: Technical report (U.S. Army Engineer Waterways Experiment Station) ; EL-97-18.

TA7 W34 no.EL-97-18 


\section{Contents}

Preface $\ldots \ldots \ldots \ldots \ldots \ldots \ldots \ldots \ldots \ldots \ldots$ iv

Conversion Factors $\ldots \ldots \ldots \ldots \ldots \ldots \ldots \ldots \ldots \ldots \ldots$ vi

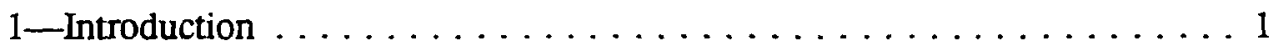

$2-$ Methods $\ldots \ldots \ldots \ldots \ldots \ldots \ldots \ldots \ldots \ldots \ldots \ldots \ldots \ldots \ldots$

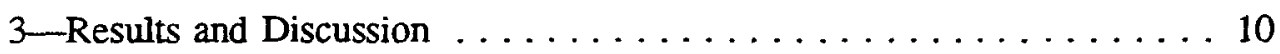

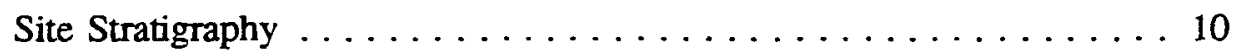

Hydrosparge Investigations . . . . . . . . . . . . 13

Surface Water Investigation of Woodrest Creek . . . . . . . . 16

Validation of Hydrosparge Results $\ldots \ldots \ldots \ldots \ldots \ldots$

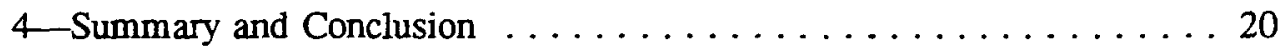

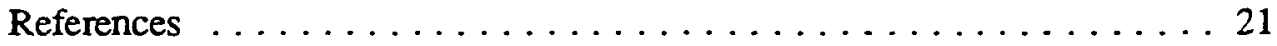

Appendix A: SCAPS Sensor Panel Plots . . . . . . . . . A1

SF 298

\section{List of Figures}

Figure 1. Map showing APG location $\ldots \ldots \ldots \ldots \ldots \ldots \ldots$

Figure 2. Map showing Building 525 site within APG $\ldots \ldots \ldots 3$

Figure 3. Diagram detailing Building 525 site . . . . . . . . 4

Figure 4 . The SCAPS system $\ldots \ldots \ldots \ldots \ldots \ldots \ldots$

Figure 5. The Hydrosparge system $\ldots \ldots \ldots \ldots \ldots \ldots$

Figure $6 . \quad$ View of SCAPS stratigraphic data $\ldots \ldots \ldots \ldots \ldots \ldots$

Figure $7 . \quad$ View of entire site stratigraphy $\ldots \ldots \ldots \ldots \ldots \ldots$

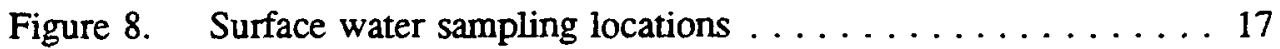

Figure 9. Comparison of validation and Hydrosparge data . . . . . 19 


\section{Preface}

This report was prepared by the Environmental Laboratory (EL) of the U.S. Army Engineer Waterways Experiment Station (WES), Vicksburg, MS. The research was funded under the Tri-Service Site Characterization and Analysis Penetrometer System (SCAPS) Program by the U.S. Army Environmental Center (AEC). The Program is managed by Dr. John Cullinane, WES, and Mr. George Robitaille was the Technical Monitor for the AEC. Personnel who cooperated in the execution of the study and the preparation of this report include Dr. William M. Davis, Principal Investigator, Ecosystem Processes and Effects Branch (EPEB), Environmental Processes and Effects Division (EPED), and Mr. Karl F. Konecny, Environmental Engineering Division, EL;

Mr. Jeff F. Powell, Instrumentation Services Division, Information Technology Laboratory (ITL); Mr. S. Paul Miller, Hydrogeology and Site Characterization Section, and Mr. Stanley M. Swartzel, Geologic Environments Analysis Section, Earthquake Engineering and Geophysics Division (GG), Geotechnical Laboratory (GL); and Mr. Donald Harris, Public Works Division, WES.

This report was reviewed by Mr. John Ballard, Assistant Program Manager, SCAPS, and Dr. Judy Pennington, EPED. This report was prepared under the general supervision of Dr. Robert Kennedy, Acting Chief, EPEB; and Mr. Joseph R. Curro, Jr., Chief, Engineering Geophysics Branch, GG; Dr. Richard E. Price, Chief, EPED; Dr. Arley G. Franklin, Chief, GG; Dr. John Harrison, Director, EL; and Dr. William F. Marcuson III, Director, GL.

At the time of publication of this report, Dr. Robert W. Whalin was Director of WES. 
This report should be cited as follows:

Davis, W. M., Powell, J. F., Miller, S. M., and Swartzel, S. P. (1997). "SCAPS investigation of chlorinated volatile organic compounds in groundwater at Building 525, Aberdeen Proving Ground, Maryland," Technical Report EL-97-18, U.S. Army Engineer Waterways Experiment Station, Vicksburg, MS. 


\section{Conversion Factors, Non-SI to SI Units of Measurement}

Non-SI units of measurement used in this report can be converted to SI units as follows:

\begin{tabular}{|l|l|l|}
\hline Multiply & By & To Obtain \\
\hline \hline cubic feet & 0.02831685 & cubic meters \\
\hline feet & 0.3048 & meters \\
\hline inches & 0.0254 & meters \\
\hline miles (U.S. statute) & 1.609347 & kilometers \\
\hline tons (2,000 pounds, mass) & 907.1847 & kilograms \\
\hline
\end{tabular}




\section{Introduction}

Aberdeen Proving Ground (APG) is a U.S. Amy research test and evaluation center located approximately 20 miles $^{1}$ northeast of Baltimore, $\mathrm{MD}$ (Figure 1). Research and field testing of various vehicles and weapon systems have been conducted at APG since 1917. Building 525 at APG was constructed during World War II in the northeast portion of APG (Figure 2) and was used by the Aberdeen Test Center (ATC) to support testing. Activities in and around the building site such as cleaning, packaging, and painting of large gun barrels and military rolling stock have required use of large quantities of solvents and petroleum products.

In past times, a railroad track through Building 525 allowed artillery and other equipment to be brought into the building, unpacked, cleaned, and then transported to ranges. The equipment was returned to Building 525 for cleaning, painting, and repacking for transport off post. A contamination assessment report described solvent tanks located within Building 525 and discussed the use and disposal of the solvents (General Physics Corporation 1995). Practices at an abandoned wash rack at the east comer of Building 525 were also described.

In addition to activities in and around the building site and practices at the wash rack area, underground storage tanks (USTs) and sewers were identified as possible sources of contamination (Figure 3). An 18-in. concrete storm sewer and sanitary sewer lines run along the southeast side of the building. The storm sewer drains into Woodrest Creek approximately $250 \mathrm{ft}$ from the southem comer of Building 525. Two USTs at the site were removed from service under the APG UST program. A fuel oil UST partially beneath the building was abandoned in place and filled with sand in November 1991. A 43-year-old solvent UST located approximately $100 \mathrm{ft}$ from the building was removed along with $169 \mathrm{ft}^{3}$ of soil in November 1993. Although piping above the tank had deteriorated, integrity testing showed the tank was intact.

Because of soil contamination found during excavation of the solvent tank, APG contracted General Physics Corporation to conduct a preliminary contamination assessment (PCA) of the site (General Physics Corporation 1994).

\footnotetext{
' A table of factors for converting non-SI units of measurement to SI units is presented on page vi.
} 


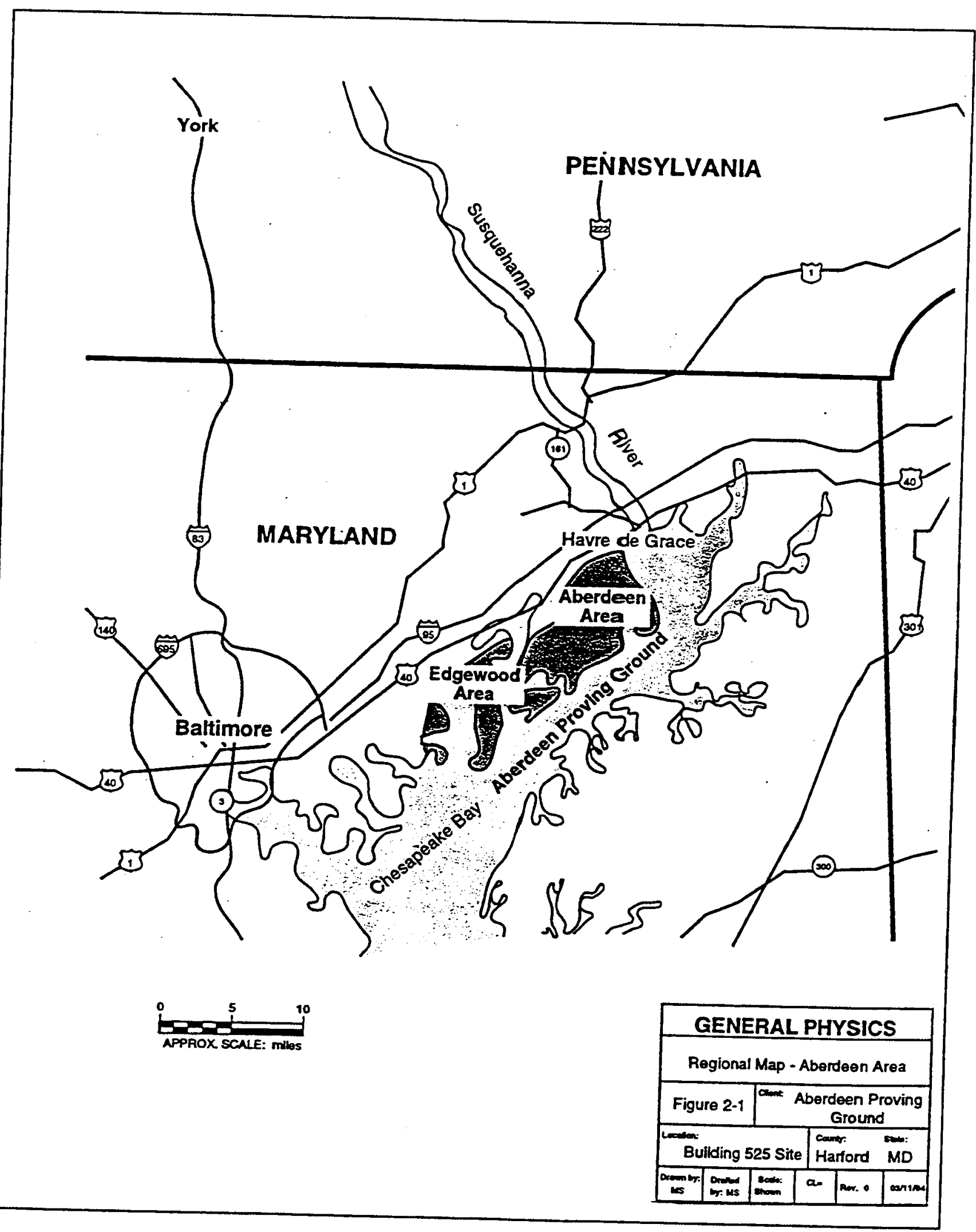

Figure 1. Map showing APG location 


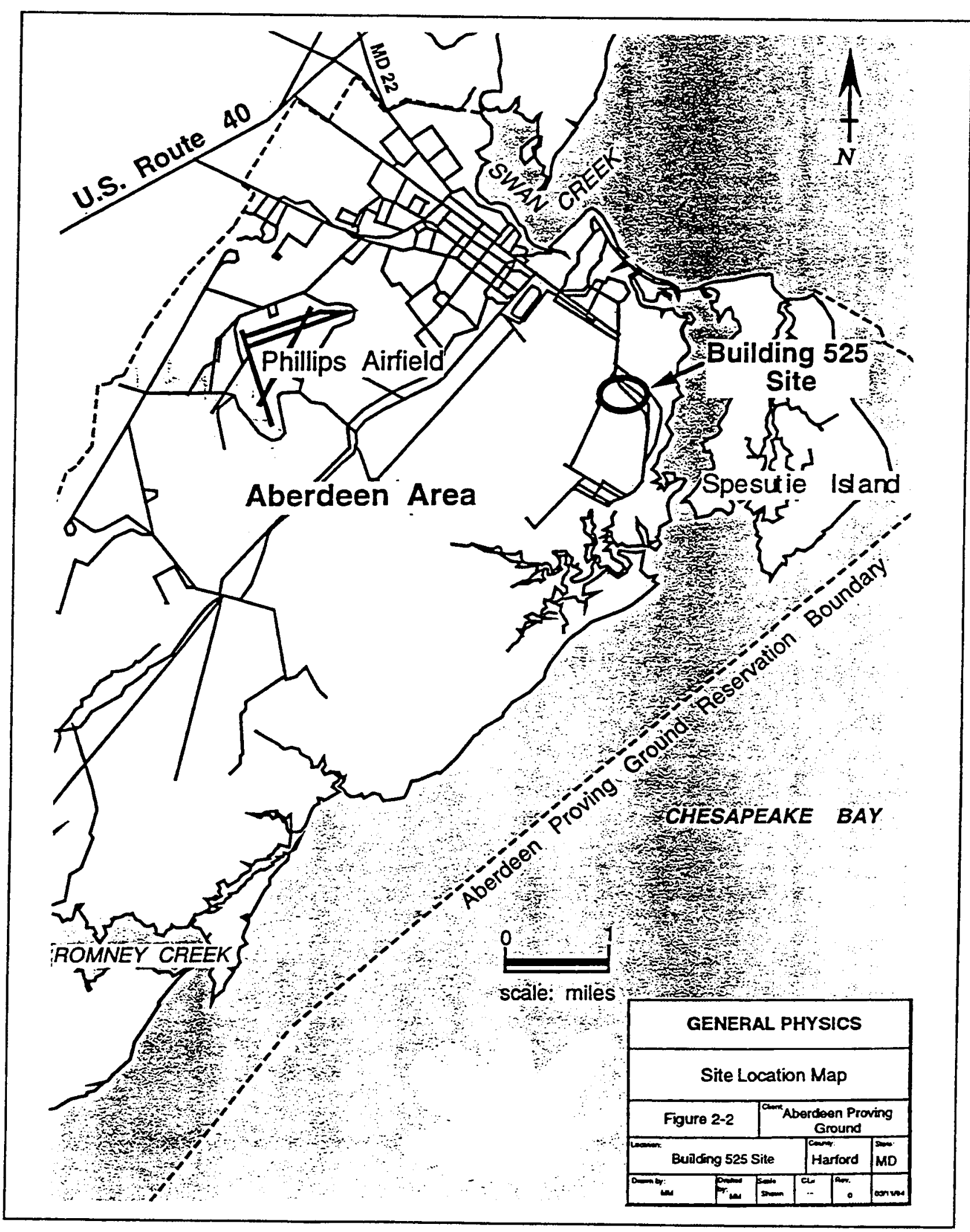

Figure 2. Map showing Building 525 site within APG 


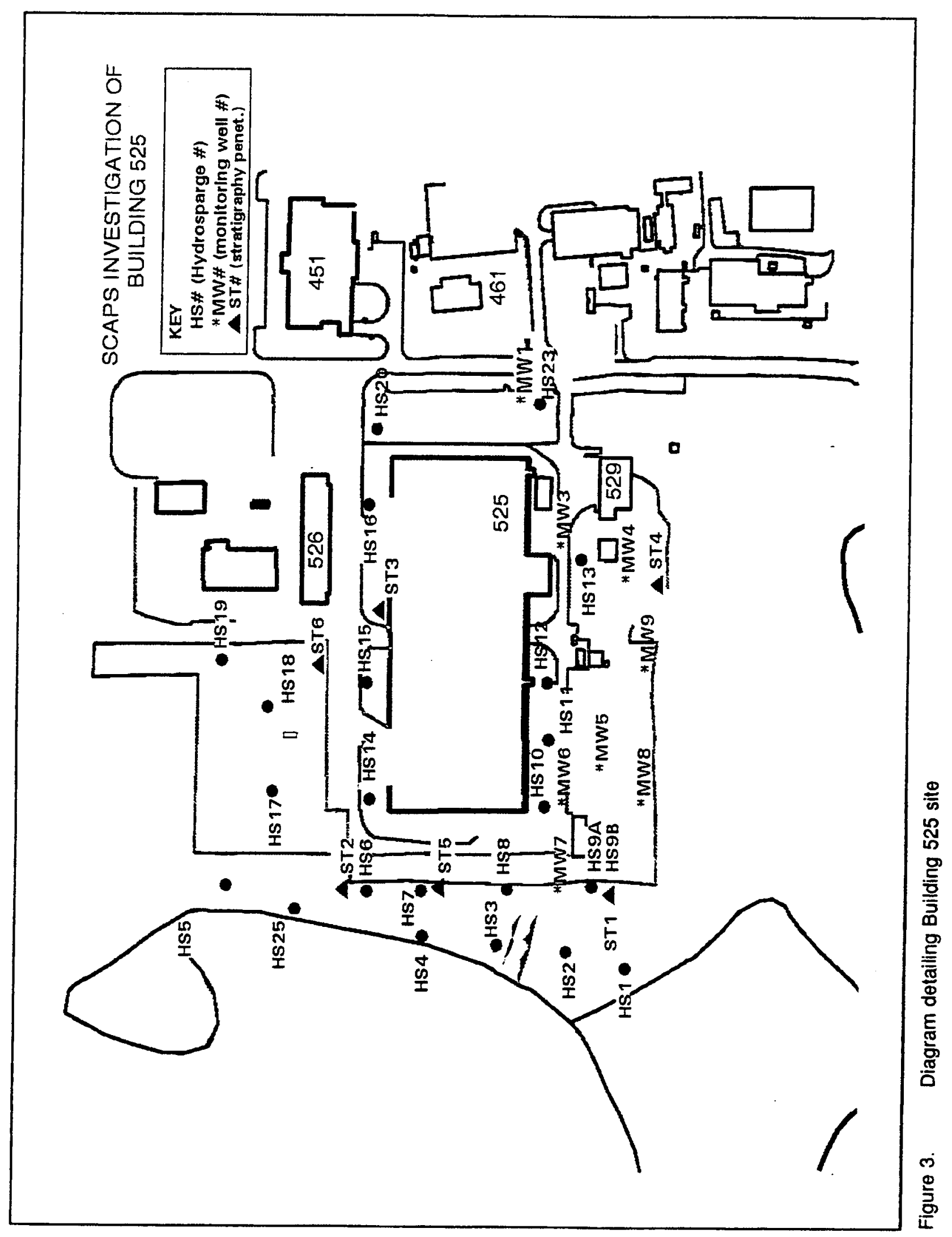


Using a Geoprobe sampling system, samples of soil were taken in 16 locations at three depths, and groundwater samples were taken from the water table in 22 locations along the southeastern side of Building 525. An onsite portable gas chromatograph (GC) was used to analyze all samples for benzene, toluene, ethylbenzene, and xylene (BTEX) and total volatile organic compounds (VOC). Additionally, groundwater laboratory analysis for VOC was conducted on all groundwater samples. The groundwater contained several chlorinated solvents such as 1,1,1-trichloroethane (TCA), trichloroethene (TCE), tetrachloroethene (PCE), and 1,1-dichloroethane (DCA).

Following the 1994 PCA, a more extensive investigation was conducted to further characterize site contamination (General Physics Corporation 1995). More Geoprobe sampling was conducted; five soil borings and 10 monitoring wells were made; and surface water and the wells were sampled. Chlorinated compounds were found in a shallow aquifer ranging in depth from 15 to $30 \mathrm{ft}$ and in the surface water of Woodrest Creek. Only the areas east, southeast, and south of the building were examined. The report recommended further investigation of the Building 525 site, including deeper aquifers, surface waters, and sewers.

In May 1995, the U.S. Army Environmental Center (AEC) at APG coordinated a field demonstration/validation of the Site Characterization and Analysis Penetrometer System (SCAPS) at Building 525. The APG Directorate of Safety, Health, and Environment (DSHE) and the U.S. Army Engineer Waterways Experiment Station (WES) developed a plan to investigate subsurface VOC contamination at the Building 525 site using SCAPS. Personnel of AEC, DSHE, ATC, and WES designed a site characterization plan that would provide data both for validation of SCAPS sensors and for better geotechnical and contaminant definition of the site. This report details results of the SCAPS investigation. 


\section{Methods}

The SCAPS consists of the cone penetrometer truck, enclosed support trailer containing decontamination wash water and grout pumping systems, and a mobile analytical laboratory van (Figure 4). The SCAPS sensor and sampler systems used at the Building 525 site were the soil classification sensor, the Hydrosparge system, and the thermal desorption sampler. The penetrometer with its associated sensor and sampler systems is advanced into the soil using a hydraulic ram, with the SCAPS truck providing a 20-ton reaction mass. A digging clearance was obtained prior to performing any penetrations in compliance with APG regulations and the SCAPS APG Safety Plan.

The SCAPS soil classification sensor measures resistance to penetration and sleeve friction. Strain gauges mounted in the penetrometer cone tip and sleeve measure these forces and provide soil classification in accordance with procedures described in American Society for Testing and Materials (ASTM) Method D3441 (ASTM 1995). For a more detailed description of the SCAPS soil classification sensor, see Lee et al. 1993. Normal operating procedures include calibration of the soil classification sensor at the beginning of each investigation and calibration checks periodically during normal operations.

The Hydrosparge (HS) system consists of a Hydropunch (HP) temporary well, an in situ sparge (IS) device, and an ion-trap mass spectrometer (ITMS). The normal operating procedures for the Hydrosparge system of investigating groundwater contamination include first accessing the groundwater using the $\mathrm{HP}$. The HP is a temporary well that can be screened for a maximum of $4 \mathrm{ft}$. The HP was pushed to the depth of interest and the push pipe was retracted, exposing the screen to the groundwater. The height of the water in the HP was monitored with a conductivity meter. The time and the depth to groundwater were recorded. The measurements at Building 525 were performed with the HP screen fully opened, with one exception.

When the water level was stable, the IS device was lowered into the well. The IS device was operated at the groundwater surface, but sampled the water 18 in. below the groundwater surface in the well. The sparge device purged the VOC analytes in situ from the groundwater using He gas and transferred the analytes to the surface via a Teflon transfer line. The operation of the HS is illustrated in Figure 5. The analyte stream was directly interfaced to the 


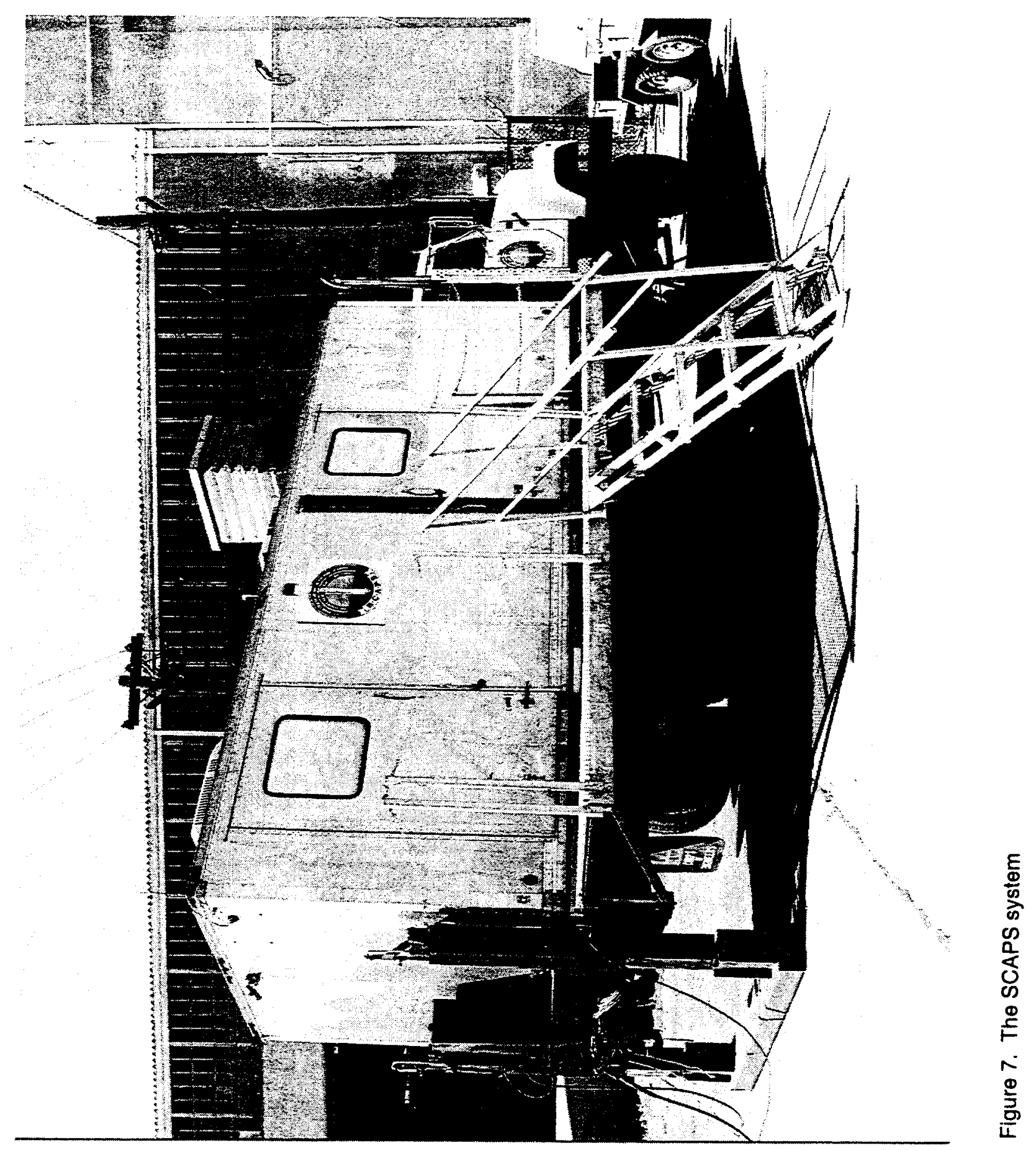




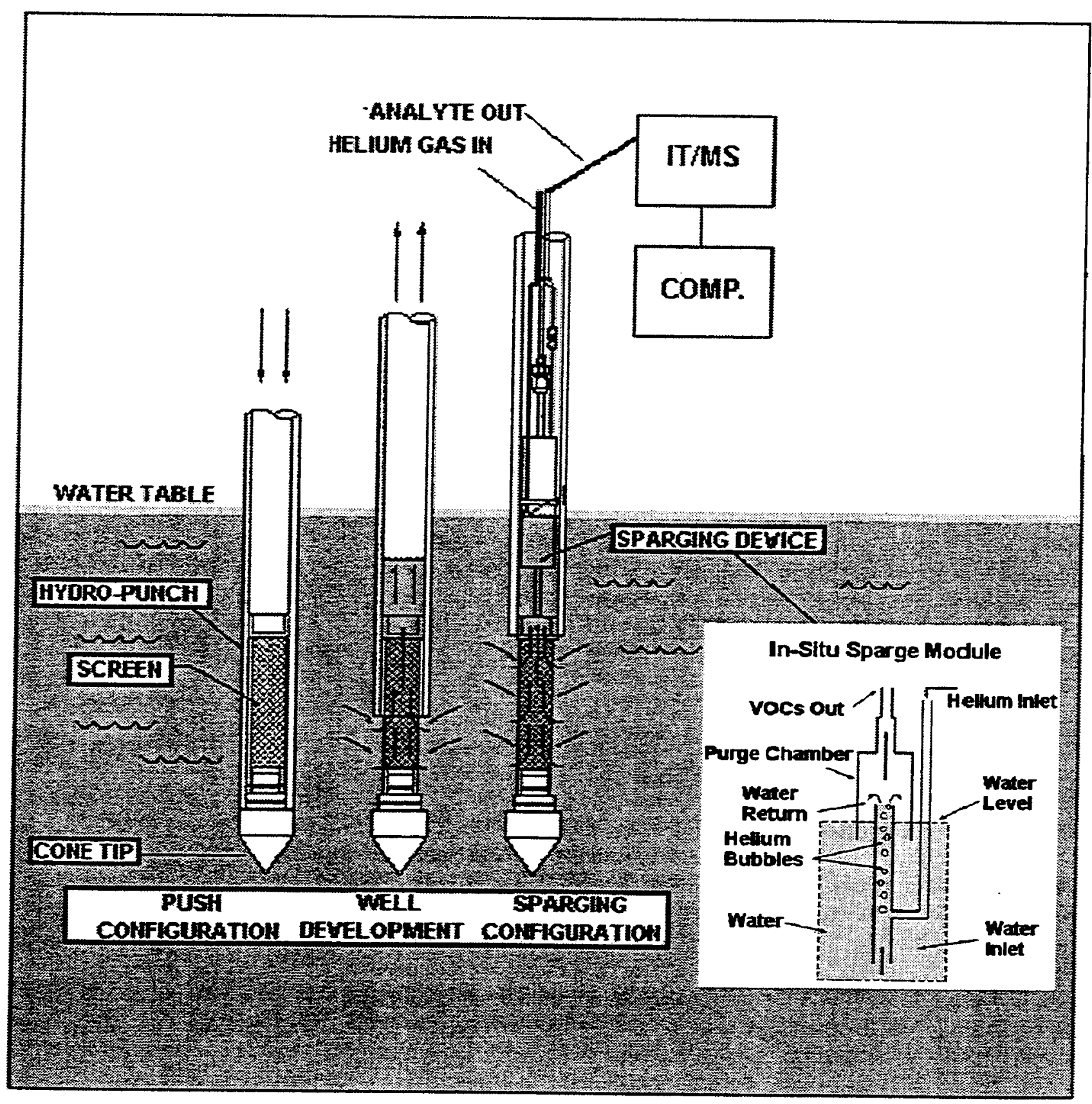

Figure 5. The Hydrosparge system 
ITMS (Teledyne Electronics Technologies), and the VOC contaminants were analyzed.

The ITMS was operated in the full scan mode and data were acquired from the well for 4 to $5 \mathrm{~min}$. The ITMS is capable of both qualitative identification of analytes based on their mass spectra and of quantitative measurement based on the intensities of analyte specific ions in the mass spectra. The Hydrosparge system was calibrated at the beginning of each deployment by spiking stock solutions of analytes into distilled water in a 250 -mL flask. Blank samples and calibration standards were analyzed to create a calibration curve over a range of concentration (e.g., 5 to $500 \mu \mathrm{g} / \mathrm{L}$ ). A calibration check standard and distilled water blank were analyzed before each HS investigation to confirm that the Hydrosparge system was within calibration and free of interferences.

Quantitation of the Hydrosparge data was performed by integrating intensities for characteristic masses for a fixed number of ITMS scans for each analyte. The integrated intensities for the calibrations were regressed against the analyte concentration to yield the calibration curves. The concentration of the analyte in the groundwater was calculated by integrating the same fixed number of scans for the characteristic masses from the data acquired during the Hydrosparge measurement and by using the regression equation from the calibration curve.

After completing the Hydrosparge measurement, a Teflon bailer equipped with a bottom-filling ball valve was used to sample groundwater for verification analysis. The bailer was gently lowered into the HP well and allowed to fill. The bailer was used to fill three $40-\mathrm{mL}$ VOC vials (preserved with $\mathrm{H}_{2} \mathrm{SO}_{4}$ ) that were immediately placed on ice for storage until they were shipped for laboratory analysis. Samples were analyzed in the laboratory by U.S. Environmental Protection Agency (EPA) Method 8260 (EPA 1995). The data obtained from analysis of verification samples were compared with the results obtained with the Hydrosparge. After the IS/ITMS measurement and verification sampling were completed, the HP was retracted, leaving the tip and screen in place. The resulting penetration hole was immediately grouted to prevent downward migration of contaminants.

The HS investigations at the Building 525 site were performed from 14 August 1995 through 20 August. Surface water samples were obtained from Woodrest Creek near low tide on 23 August along a transect running in the creek from approximately $120 \mathrm{ft}$ downstream to $120 \mathrm{ft}$ upstream from the storm water drain. Twelve surface water locations were sampled by submerging 40-mL VOC vials and carefully sealing the filled vials with no headspace. The samples were analyzed in the SCAPS van using EPA Method 8265, which uses the ITMS with a vial sparge interface, and which was given provisional approval under EPA Methods for Analysis of Solid and Hazardous Waste. ${ }^{1}$

\footnotetext{
I Personal Communication, 1996, B. Lesnik, Office of Solid Waste, U.S. Environmental Protection Agency, Washington, DC.
} 


\section{Results and Discussion}

\section{Site Stratigraphy}

Previous investigations of the area adjacent to the south side of Building 525 consisted of Geoprobe penetrations to sample soil and/or groundwater, five soil borings for geophysical characterization, and 10 groundwater monitoring wells (General Physics Corporation 1995). These investigations indicated surficial fill in some areas, followed by clay, silt, and silt/clay mixes to a depth of 10 to $15 \mathrm{ft}$ below ground surface (BGS). Below that depth, the boring logs indicated sand and sand/gravel mixes with narrow interbedded clay and silt/clay lenses to 25 to $30 \mathrm{ft}$ BGS (see Figures 5-1, 5-2, and 5-3 in General Physics Corporation 1995). The depth to groundwater for the surficial aquifer was generally observed to be 12 to $15 \mathrm{ft}$ BGS, and that aquifer was assumed to be unconfined.

All the soil borings and monitoring wells were terminated between 25 and $30 \mathrm{ft}$ BGS except for SB01. This boring was located at the southeast comer of Building 525 and was performed to a depth of $71.5 \mathrm{ft}$. This boring indicated

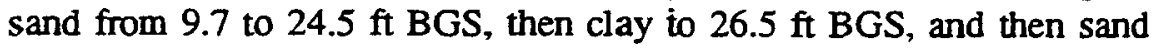
(including gravelly sands and silty fine sands) to $57 \mathrm{ft}$ BGS. Two narrow bands of clay were found at 57.2 to $58.3 \mathrm{ft}$ BGS and 60 to $60.5 \mathrm{ft} \mathrm{BGS}$. The interval from 66 to $70 \mathrm{ft}$ BGS was reported to be clay, with sandy clay observed to $71.5 \mathrm{ft}$ BGS. Since only one boring was performed to a depth below $30 \mathrm{ft}$, the lower confining layer for the surficial aquifer was not well defined. Some of the soil borings and monitoring wells indicated a corresponding clay layer above $30 \mathrm{ft}$ BGS (SB01, SB02, MW03, MW05, MW06), while others did not (SB4, MW08, and MW10).

A number of SCAPS stratigraphic penetrations were executed to address the lack of data at depths greater than $30 \mathrm{ft}$ BGS. Initial plans called for five SCAPS stratigraphic penetrations to be performed in areas south, west, and north of the building, with additional penetrations performed as time permitted. The penetrations were planned to investigate subsurface stratigraphy to $100 \mathrm{ft}$ BGS where possible. The stratigraphic penetrations west and north of Building 525 were planned to provide geologic data in areas of the site not previously investigated. 
Six stratigraphic penetrations were performed during the 2 working days (12 and 13 August 1995) allotted to investigate the subsurface site geology. There were two penetrations south and east of the building (ST01 and ST04, see Figure 3), one southwest of the building (ST05), and three west and north of the building (ST02, ST03, and ST06). The stratigraphic penetrations performed on the south side of Building 525 were near borings for the previous investigations. ST04 was performed near the previous soil boring SB04, and ST05 was performed near previous monitoring well MW07. SCAPS penetration ST04 was pushed to $99 \mathrm{ft}$ BGS, while SB04 went to $29 \mathrm{ft}$ BGS; and ST05 went to $55 \mathrm{ft} \mathrm{BGS,} \mathrm{while} \mathrm{MW07} \mathrm{went} \mathrm{to} 30 \mathrm{ft}$ BGS. There were no previous subsurface investigations near the other SCAPS stratigraphic penetrations.

Data obtained from ST04 and ST05 indicated subsurface geology quite similar to that obtained from SB04 and MW07, respectively. The SCAPS data obtained for ST04 (Figure A4 in Appendix A) indicated sand/silt and silt/clay mixes from the surface to $9.5 \mathrm{ft}$ BGS. The boring log for SB04 (Figure SB04, Appendix E, in General Physics Corporation 1995) indicated silt, clay, and sand over this interval. The SCAPS data from 9.5 to $21 \mathrm{ft} \mathrm{BGS}$ indicated sand mixes with two narrow (1 ft each) bands of silt. The log for SB04 recorded sand from 13 to $20.5 \mathrm{ft}$ BGS. Both the SCAPS and soil boring data indicated a narrow clay band at approximately $20.5 \mathrm{ft}$ BGS. The SCAPS data indicated sand mixes to $30 \mathrm{ft}$ BGS where a band of silt and silt/clay begins. SB04 indicated sand from 21.5 to $28 \mathrm{ft} \mathrm{BGS}$, then silt/clay to $29.5 \mathrm{ft}$ BGS. Comparison of the data for ST05 (Figure A5) and the nearby MW07 (Figure MW07, Appendix E, in General Physics Corporation 1995) revealed that quite similar subsurface geology was determined by these two quite different methods.

Analysis of the stratigraphic data indicated the possibility of three aquifers between the ground surface and depths of $100 \mathrm{ft}$. The surficial aquifer generally begins below $10 \mathrm{ft}$ BGS and extends to approximately $30 \mathrm{ft}$ BGS. The second aquifer begins below $30 \mathrm{ft}$ BGS and generally extends to approximately $50 \mathrm{ft}$ BGS. It should be noted that the thickness of the clay layer beginning at approximately $30 \mathrm{ft}$ BGS varies greatly over the site, and the second aquifer suggested here may actually be connected to the first. A clay layer (4 to $5 \mathrm{ft}$ thick) was detected at approximately $50 \mathrm{ft}$ BGS, and below this an interval of approximately $30 \mathrm{ft}$ of sand was detected (Figures A1 and A4). The clay layer below this sand appeared to be at least $20 \mathrm{ft}$ thick, suggesting a well-confined third aquifer.

The data produced by the SCAPS stratigraphic sensor can be used to produce a three-dimensional (3-D) visualization of the subsurface geology at any particular site (Lee et al. 1994; Davis et al. 1997). The large area and low density of penetrations at the Building 525 site reduced the usefulness of such a visualization. However, the 3-D visualization (Figure 6) produced for the six stratigraphic penetrations performed at this site is informative. Since the SCAPS stratigraphic data were similar to the previous soil boring and monitoring well stratigraphic data as discussed above, the two data sets were 


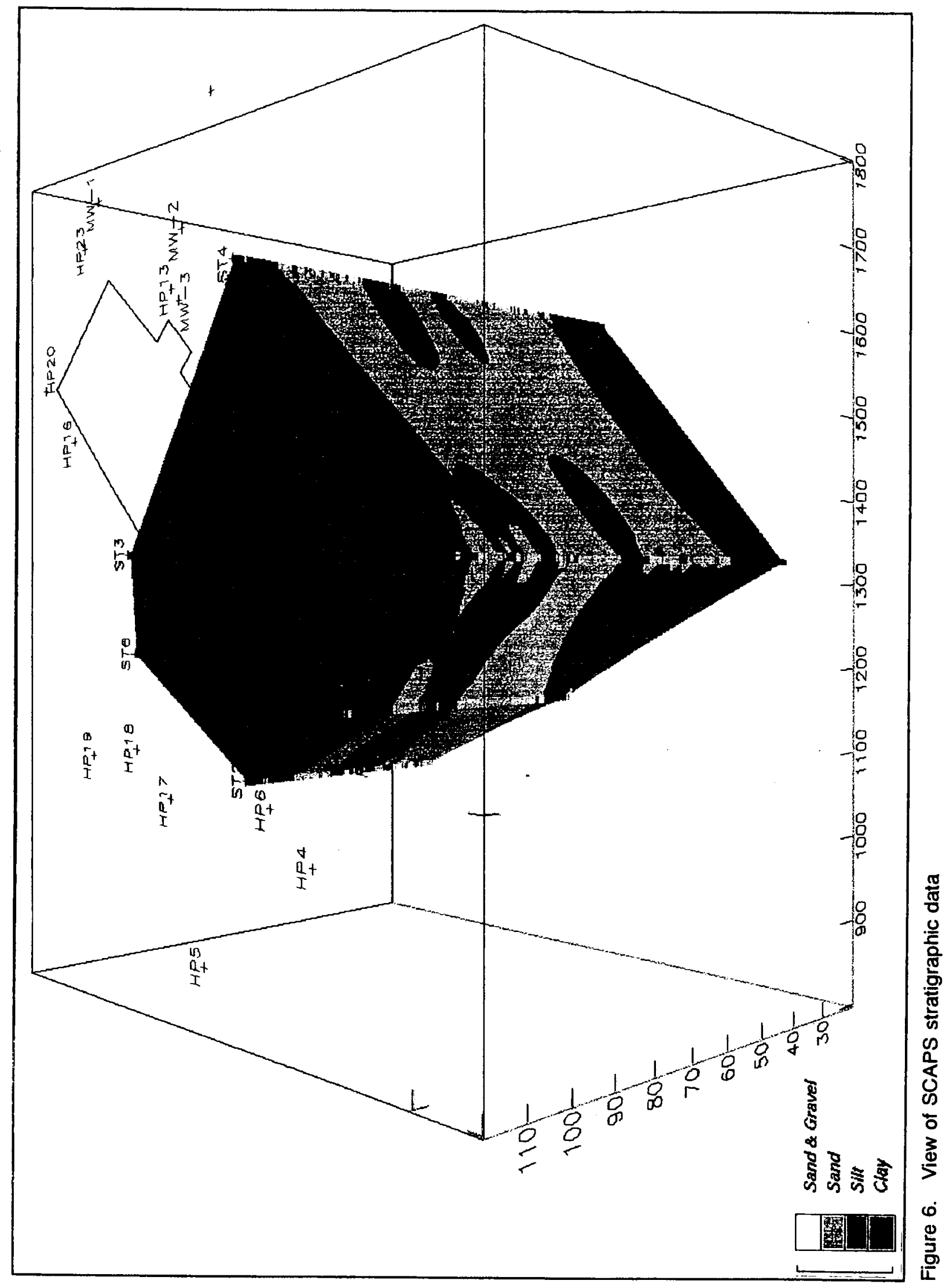


combined. The soil boring and monitoring well data were converted to equivalent SCAPS stratigraphic data. These data were then combined with the SCAPS data to produce a 3-D visualization of the entire site stratigraphy (Figure 7).

\section{Hydrosparge Investigations}

Previous investigations of soil and groundwater contamination on the south side of Building 525 consisted of approximately 40 Geoprobe borings for soil and groundwater sampling and the installation of 10 monitoring wells for groundwater sampling (General Physics Corporation 1995). Results of laboratory analyses from these investigations indicated chlorinated organic compounds in soil and groundwater. The chlorinated VOC contaminants in this area were TCA, TCE, and their breakdown products. Suspected sources of the contaminants in this area were a wash rack near the southeast end of the building and a recently removed solvent UST west of Building 525 (Figure 3).

The previous investigations indicated that the VOC contaminants in the surficial aquifer were migrating toward Woodrest Creek on the west side of the site (General Physics Corporation 1995). Study of contamination patterns on the southwest side of the building suggested that additional VOC sources could exist northwest of the building. Previous investigations recommended that additional characterizations of the surficial aquifer on the northwest side of Building 525 and of deeper aquifers were needed. Based on those recommendations, 25 locations were identified on all sides of Building 525 for groundwater investigation (Figure 3) using the SCAPS Hydrosparge. The numeric labels of HP locations do not represent any special order.

The Hydrosparge groundwater investigations performed north and west of Building 525 detected no VOC contamination at the north end of the building (HS16 and HS20 - see Table 1). Significant VOC contamination was detected west of the building and in the vehicle parking area (HS14, HS17, and HS18). The source of the contamination in the west area of the Building 525 site appeared to be different from that affecting the southeast area, based on the ratios of concentrations of TCA to TCE. The ratios for southeast HP locations were mostly equal (and greater than one) despite the wide range of concentrations, while the contamination for west locations was predominantly TCE with much less TCA. Since the west locations with the most TCE were HS17 and HS18, the source of the TCE contamination in the northwest area was probably near HS17 and HS18.

The HS experiments performed on the southeast side of Building 525 yielded TCA and TCE groundwater concentrations similar to the results obtained in the previous investigations. For example, HS11 detected $270 \mu \mathrm{g} / \mathrm{L}$ TCA and $176 \mu \mathrm{g} / \mathrm{L}$ TCE, while MW05, the closest well, detected $257 \mu \mathrm{g} / \mathrm{L}$ TCA and $199 \mu \mathrm{g} / \mathrm{L}$ TCE (Table 5-4, General Physics Corporation 1995). The $\mathrm{HP}$ wells were generally screened from 10 to $22 \mathrm{ft}$ BGS in this area, and the screen intervals for the monitoring wells near HS locations always bracketed 


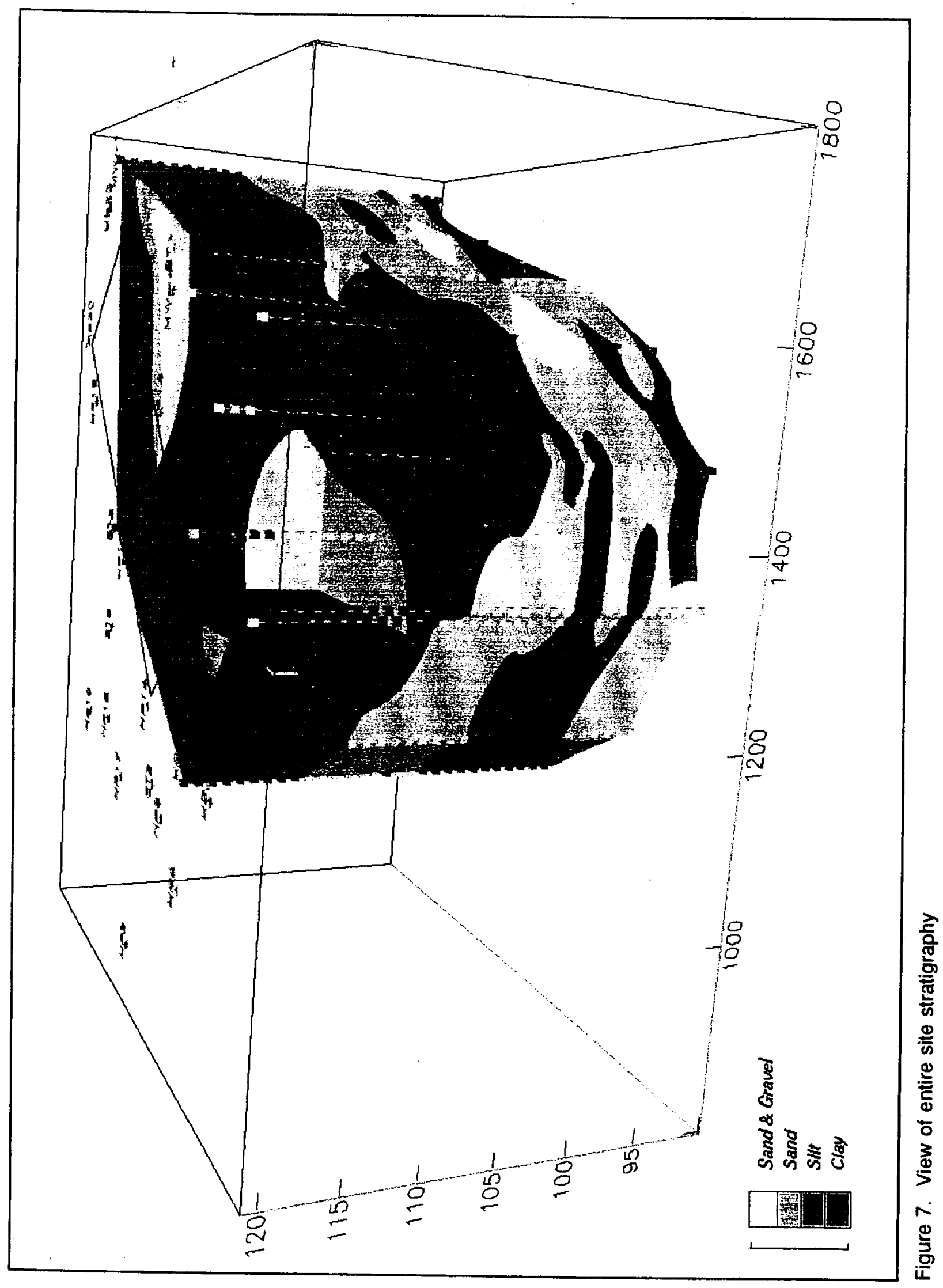




\begin{tabular}{|c|c|c|c|c|c|c|c|}
\hline \multicolumn{8}{|c|}{$\begin{array}{l}\text { Table } 1 \\
\text { SCAPS Hydrosparge Investigation Data From APG, 14-20 August } 1995\end{array}$} \\
\hline $\begin{array}{l}\text { Sample } \\
\text { Name }\end{array}$ & $\begin{array}{l}\text { Hydrosparge } \\
\text { TCA, ng/mL }\end{array}$ & $\begin{array}{l}\text { EPA } 8260 \\
\text { TCA, ng/mL }\end{array}$ & $\begin{array}{l}\text { Hydrosparge } \\
\text { TCE, ng/mL }\end{array}$ & $\begin{array}{l}\text { EPA } 8260 \\
\text { TCE, ng/mL }\end{array}$ & $\begin{array}{l}\text { Screen } \\
\text { ft BGS }\end{array}$ & $\begin{array}{l}\text { Water Table } \\
\text { ft BGS }\end{array}$ & Date \\
\hline HSO1 & 51 & 61 & 5 & 19 & 16-12 & 10 & $15 / 8$ \\
\hline HSO2 & 254 & 200 & 111 & 140 & $14-10.8$ & 7.3 & $15 / 8$ \\
\hline $\mathrm{HSO3}$ & 155 & 32 & 121 & 160 & 15-11 & 10.2 & $17 / 8$ \\
\hline $\mathrm{HSO4}$ & 17 & $<5$ & 10 & $<5$ & $15-11$ & 8.4 & $16 / 8$ \\
\hline HSOS & 15 & 21 & $<5$ & 7.7 & 15-11 & 4.9 & $16 / 8$ \\
\hline HSO6 & $<5$ & 12 & 180 & 220 & 20-16 & 17 & $16 / 8$ \\
\hline HSO7 & 14 & 31 & 172 & 420 & $20-16$ & 16.5 & $16 / 8$ \\
\hline HSO8 & 219 & 240 & 120 & 200 & $21-17$ & 17.2 & $15 / 8$ \\
\hline HSOSA & $<5$ & $<5$ & $<5$ & $<5$ & $70-66$ & 19 & $14 / 8$ \\
\hline HSO9B & $<5$ & $<5$ & $<5$ & 12 & $45-41$ & 18 & $15 / 8$ \\
\hline HS10 & 685 & 510 & 398 & 450 & $22-18$ & 17.3 & $20 / 8$ \\
\hline HS11 & 270 & 170 & 176 & 180 & 22-18 & 16.9 & $20 / 8$ \\
\hline HS12 & 1,462 & 1,300 & 942 & 1,200 & 22-18 & 16.2 & $19 / 8$ \\
\hline HS13 & 13 & 24 & $<5$ & $<5$ & 22-18 & 15.9 & $19 / 8$ \\
\hline HS14 & 18 & 19 & 172 & 250 & $20-16$ & 17.5 & $17 / 8$ \\
\hline HS15 & 16 & 13 & 27 & 30 & $20-16$ & 16.6 & $17 / 8$ \\
\hline HS16 & $<5$ & $<5$ & $<5$ & $<5$ & 22-18 & 15.4 & $18 / 8$ \\
\hline HS17 & 100 & 66 & 607 & 570 & $20-16$ & 17.2 & $19 / 8$ \\
\hline HS18 & 68 & 88 & 602 & 870 & $21-17$ & 17.8 & $18 / 8$ \\
\hline HS19 & 12 & 18 & 9 & 24 & $20-16$ & 17 & $18 / 8$ \\
\hline HS2O & $<5$ & $<5$ & $<5$ & $<5$ & 22-18 & 14.6 & $18 / 8$ \\
\hline HS 23 & 6 & $<5$ & 59 & $<5$ & $21.8-17.8$ & 15.2 & $19 / 8$ \\
\hline HS25 & $<5$ & $<5$ & 34 & $<5$ & $15-11$ & 4.5 & $19 / 8$ \\
\hline
\end{tabular}

the HS screen intervals. However, the HS measurements near MW06 were not in agreement with the TCA and TCE concentrations obtained previously for MW06. This monitoring well was between HS10 to the west and HS11 to the east, which both indicated significantly higher concentrations of VOC. MW06 indicated the presence of $11 \mu \mathrm{g} / \mathrm{L}$ TCA and $33 \mu \mathrm{g} / \mathrm{L}$ TCE, while the average of HS10 and HS11 was approximately $500 \mu \mathrm{g} / \mathrm{L}$ TCA and $300 \mu \mathrm{g} / \mathrm{L}$ TCE.

HS12 (located slightly farther east from HS11) detected the highest VOC concentrations in groundwater at this site: these concentrations were 
$1,462 \mu \mathrm{g} / \mathrm{L}$ TCA and $942 \mu \mathrm{g} / \mathrm{L}$ TCE. These data were very similar to the contaminant levels detected previously at MW03, located much farther east along the side of Building 525. MW06, HS10, HS11, and HS12 provided the only data currently available for the area at the south corner of Building 525 . The HS data obtained near MW06 indicated that there may be multiple sources or that a source near MW03 may extend westward to HS12.

VOC contamination of the two deeper aquifers was investigated by performing two different Hydrosparge measurements at location HP09. The first HS penetration at HS09 (HS09A) was performed to $70 \mathrm{ft} \mathrm{BGS,} \mathrm{and} \mathrm{the} \mathrm{well}$ was screened from 70 to $66 \mathrm{ft}$ BGS. The second penetration (HS09B) was laterally offset by just $2 \mathrm{ft}$ from the first. It was performed to $45 \mathrm{ft} \mathrm{BGS}$, and the well was screened from 45 to $41 \mathrm{ft}$ BGS. Results of analyses indicated that neither penetration encountered chlorinated VOC contaminants above a threshold concentration of $5 \mu \mathrm{g} / \mathrm{L}$ (Table 1). However, the analysis of the bailed water sample from HS09B indicated the presence of TCE at $12 \mu \mathrm{g} / \mathrm{L}$. One possible explanation is found from a more detailed consideration of the grouting procedure.

The HS penetrations were grouted after the HP tool was removed from the penetration hole. However, as the HP was retracted, flush mount 3/4-in.-ID polyvinyl chloride (PVC) pipe was lowered through the penetrometer push pipe and left in the penetration hole. Once the HP tool and push pipe had been retracted, the penetration hole was grouted using the inserted PVC pipe as a trimmie pipe. However, since the outer diameter of the HP is 2 in., there was an annular space available for possible cross contamination during the $\mathrm{HP}$ retraction before grouting was completed. Since HS09B was performed after HSO9A, and HSO8 and HS10 both indicated significant TCE contamination in the surficial aquifer (Table 1), the TCE observed in the bailed water sample obtained at HSO9B may have been from a small amount of leakage during grouting of HSO9A.

\section{Surface Water Investigation of Woodrest Creek}

In addition to the HS investigations at this site, the potential impact of the surficial groundwater contamination on Woodrest Creek was investigated. Twelve surface water samples were obtained from a transect running upstream and downstream from the storm sewer drain near the southwest comer of Building 525 (Figure 8). Samples were obtained in duplicate and analyzed onsite for TCA and TCE. Samples were taken near low tide on 23 August 1995 beginning at a location about $120 \mathrm{ft}$ downstream from the storm drain and extending to about $120 \mathrm{ft}$ upstream. The total time taken for collection and analysis of all the surface water samples was under $3 \mathrm{hr}$.

The duplicated surface water sample analyses agreed on the presence of TCA and TCE in Woodrest Creek (Table 2). Streams of groundwater were observed to be flowing into Woodrest Creek near samples C3 and C5. The 


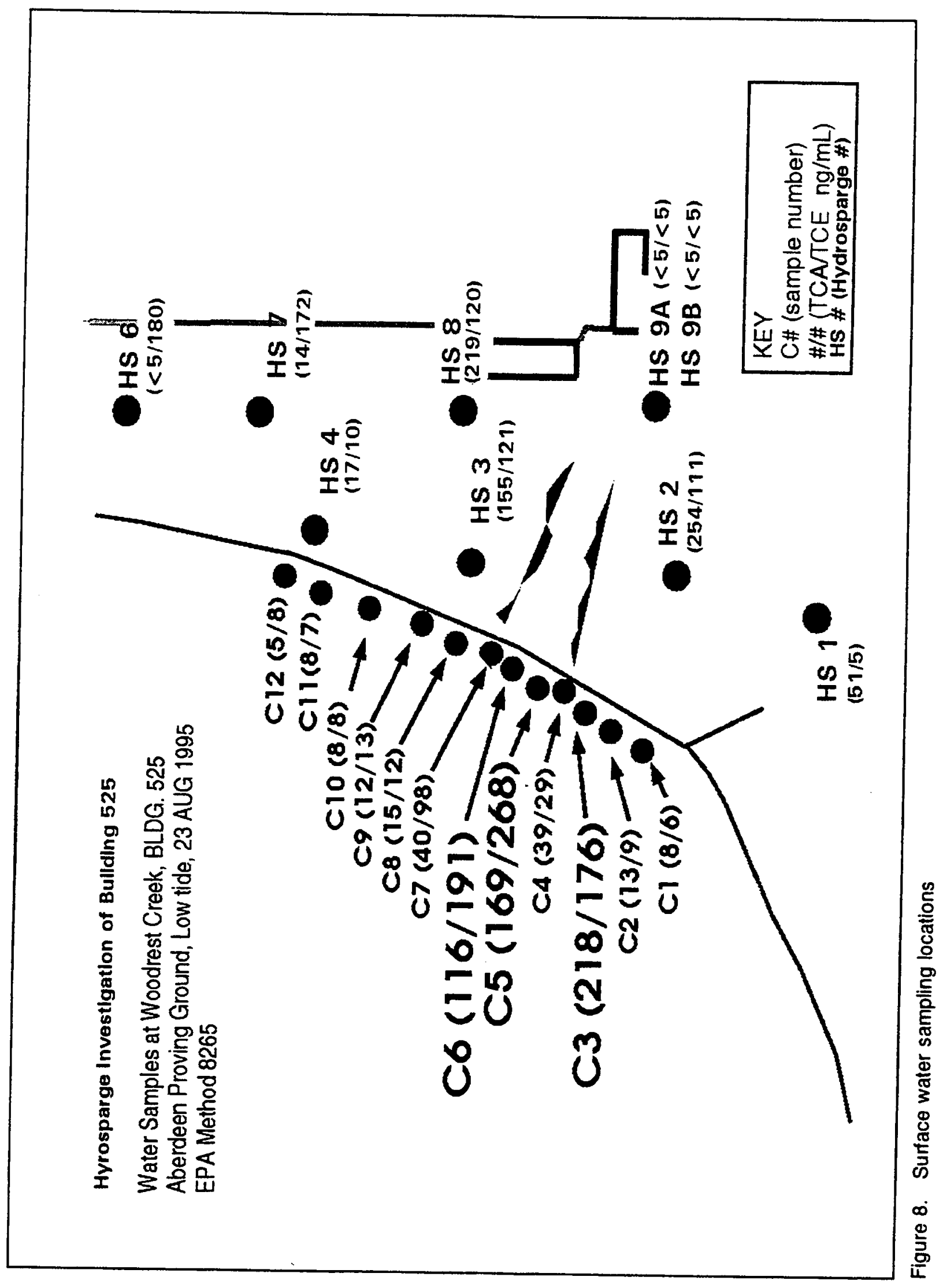

Chapter 3 Results and Discussion 


\begin{tabular}{|c|c|c|}
\hline \multicolumn{3}{|c|}{$\begin{array}{l}\text { Table } 2 \\
\text { Surface Water Data from Woodrest Creek Samples, Low Tide } 23 \\
\text { August } 1995\end{array}$} \\
\hline Sample Name & EPA $8265 \mathrm{TCA}, \mathrm{ng} / \mathrm{mL}$ & EPA $8265 \mathrm{rCE}, \mathrm{ng} / \mathrm{mL}$ \\
\hline $\mathrm{C}_{1}$ & 8 & 6 \\
\hline $\mathrm{C} 2$ & 13 & 9 \\
\hline C3 & 218 & 176 \\
\hline $\mathrm{C} 4$ & 39 & 29 \\
\hline C5 & 169 & 268 \\
\hline $\mathrm{C} 6$ & 116 & 191 \\
\hline $\mathrm{C} 7$ & 40 & 98 \\
\hline $\mathrm{c8}$ & 15 & 12 \\
\hline C9 & 12 & 13 \\
\hline C10 & 8 & 8 \\
\hline C11 & 8 & 7 \\
\hline $\mathrm{C} 12$ & 5 & 8 \\
\hline
\end{tabular}

C3, C5, and C6 sampling locations are downgradient from the locations of HSO2 and HSO3, and the contaminant concentrations in the groundwater at those locations (Table 1) are similar to those obtained for the corresponding surface water sample locations (Table 2).

\section{Validation of Hydrosparge Results}

Standard operation procedures for Hydrosparge investigations currently include validation sampling of the groundwater for each HS penetration. The samples are analyzed using EPA Method 8260 , which is a purge and trap/GC/ mass spectrometer method for quantifying VOC analytes in various matrices, including water. The samples were obtained with a $1.9-\mathrm{cm}-\mathrm{ID}$ Teflon bailer approximately $30 \mathrm{~min}$ after each Hydrosparge investigation was completed. Samples were stored on ice and shipped to the WES Analytical Laboratory Group for analysis.

The analytical results for VOC concentrations in the validation samples are given in Table 1 and are very similar to the results of corresponding Hydrosparge investigations. The laboratory data indicate that there are strong correlations between the Hydrosparge method and EPA Method 8260 for both TCA and TCE (Figure 9). Further, the slopes for both analytes are near one, indicating that both methods produce essentially identical results over a dynamic range of three orders of magnitude. 


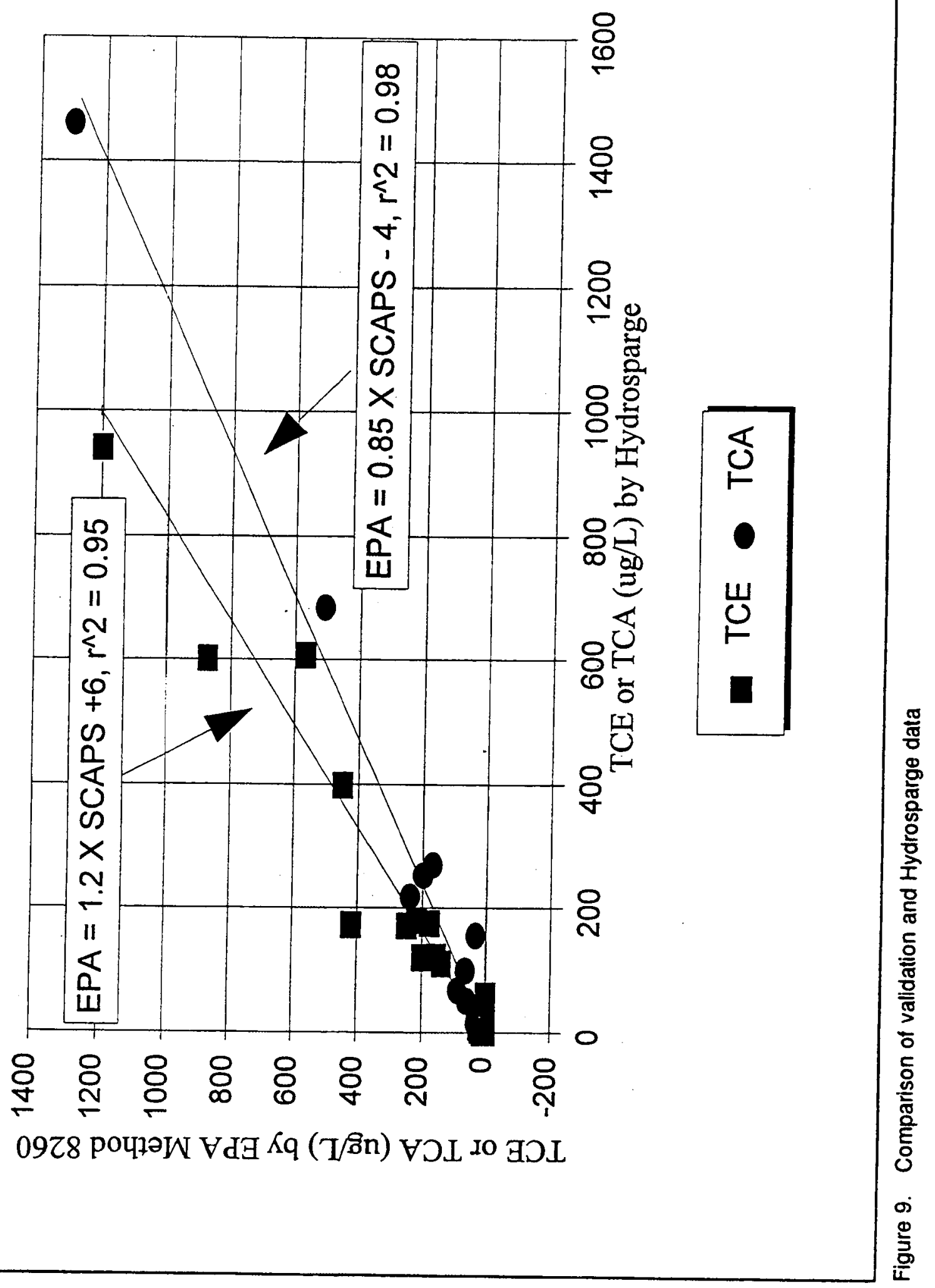




\section{Summary and Conclusion}

The Hydrosparge investigations performed at the Building 525 site confirmed the presence of TCA and TCE in the surficial groundwater southeast of the building. The results of HS10, HS11, and HS12 indicate that the source near MW03 may be larger and extend farther to the west than previously indicated. The surficial groundwater contamination does not appear to have migrated to deeper aquifers in this area.

The Hydrosparge investigations northwest of the building indicated another source of TCE contaminating the surficial groundwater near the west corner of the building. The contaminated surficial groundwater appears to be impacting Woodrest Creek in the vicinity of the storm sewer drain. 


\section{References}

American Society for Testing and Materials (ASTM). (1995). Annual book of ASTM standards. 04.08 (D-3441), Philadelphia.

Davis, W. M., Cespedes, E. R., Lee, L. T., Powell, J. F., and Goodson, R. A. (1997). "Rapid delineation of subsurface petroleum contamination using the site characterization and analysis penetrometer system," Environmental Geology 29, 228-237.

General Physics Corporation. (1994). "Preliminary contamination assessment study, Building 525 Site, Aberdeen Proving Ground, Maryland GP-R71194020," Columbia, MD.

. (1995). "Draft report contamination assessment study at Building 525 Site, Aberdeen Proving Ground, Maryland GP-R-71195040," Columbia, MD.

Lee, L. T., Chrestman, A. M., Douglas, D. H., Powell, J. F., and Malone, P. G. (1993). "Site investigations with the site characterization and analysis penetrometer system at Fort Dix, New Jersey," Technical Report GL-93-17, U.S. Army Engineer Waterways Experiment Station, Vicksburg, MS.

Lee, L. T., Davis, W. M., Goodson, R. A., Powell, J. F., and Register, B. A. (1994). "Site characterization and analysis penetrometer (SCAPS) field investigation at the Sierra Army Depot, Califomia," Technical Report GL94-4, U.S. Army Engineer Waterways Experiment Station, Vicksburg, MS.

U.S. Environmental Protection Agency. (1995). "Test methods for evaluating solid waste; Physical/chemical methods," SW-846 Third Edition, Washington, DC. 


\section{Appendix A SCAPS Sensor Panel Plots}




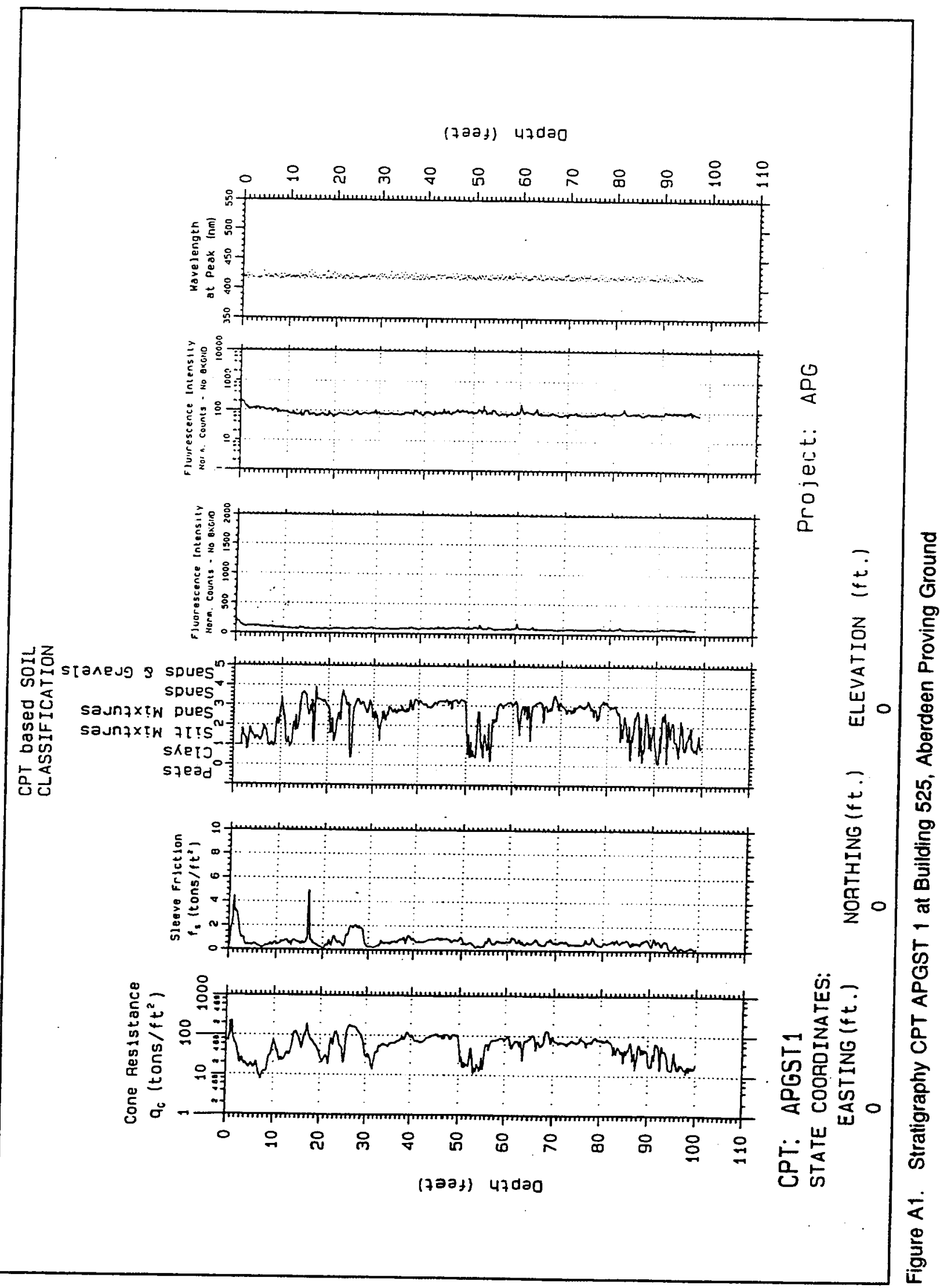




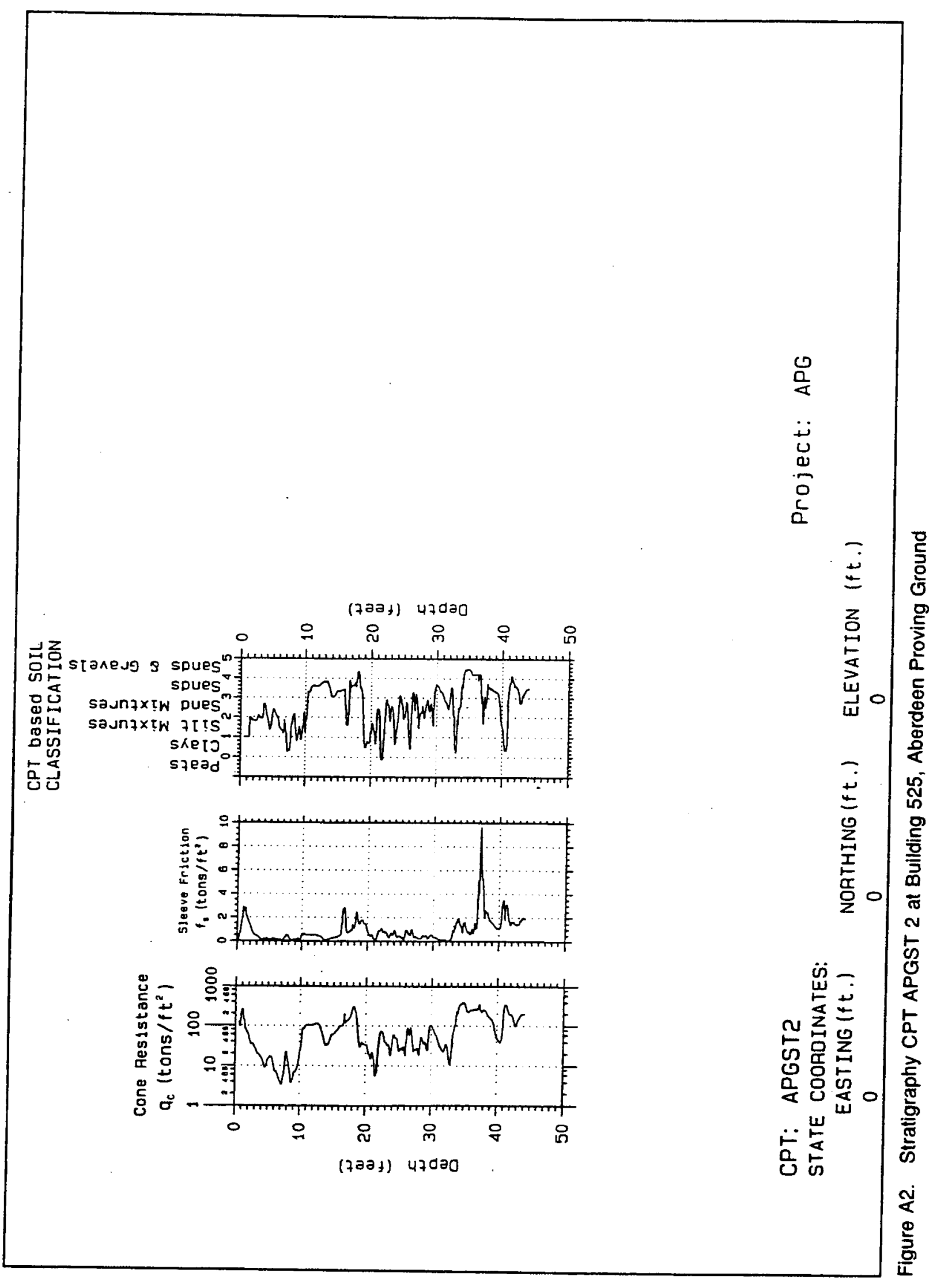




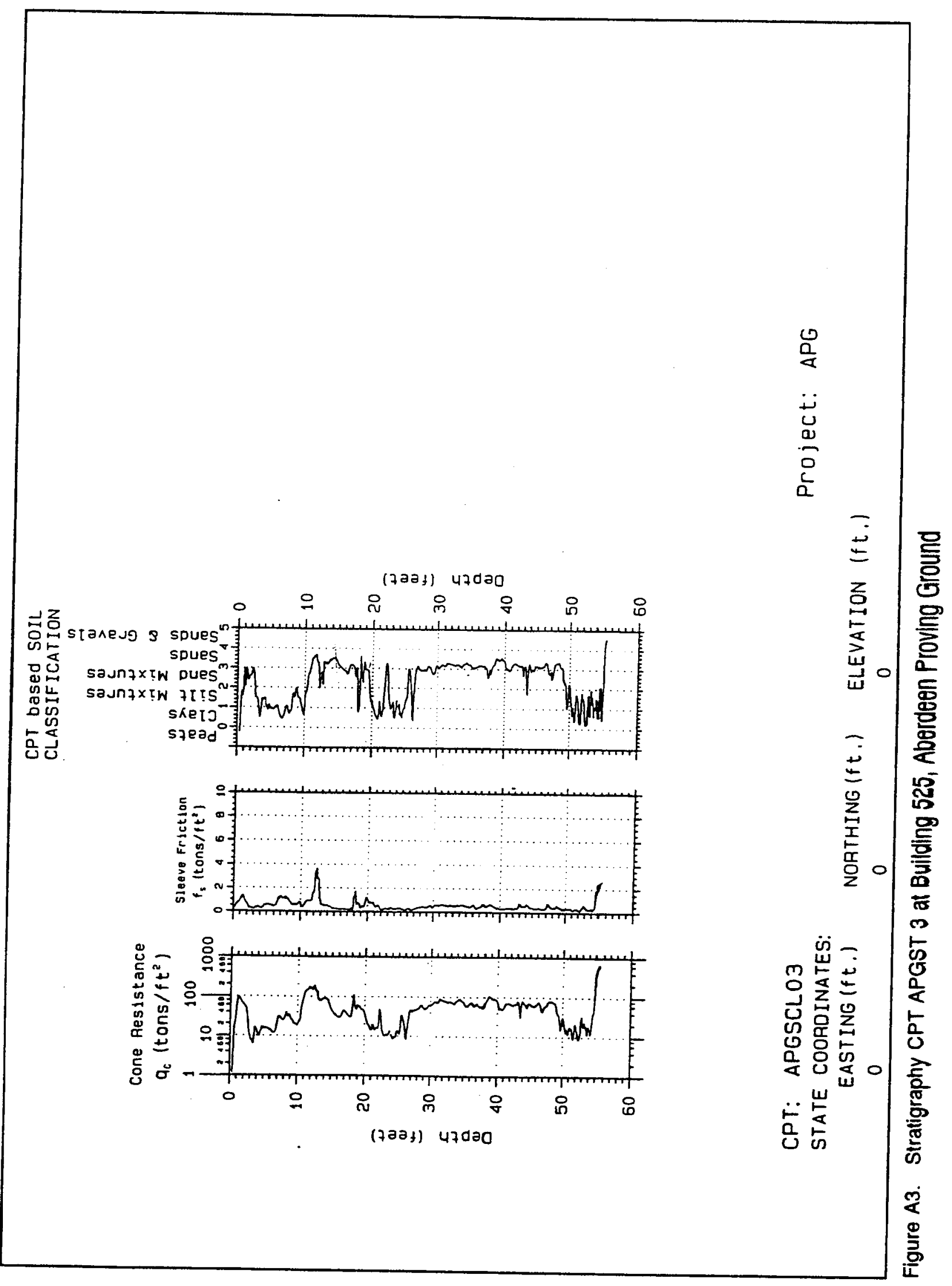




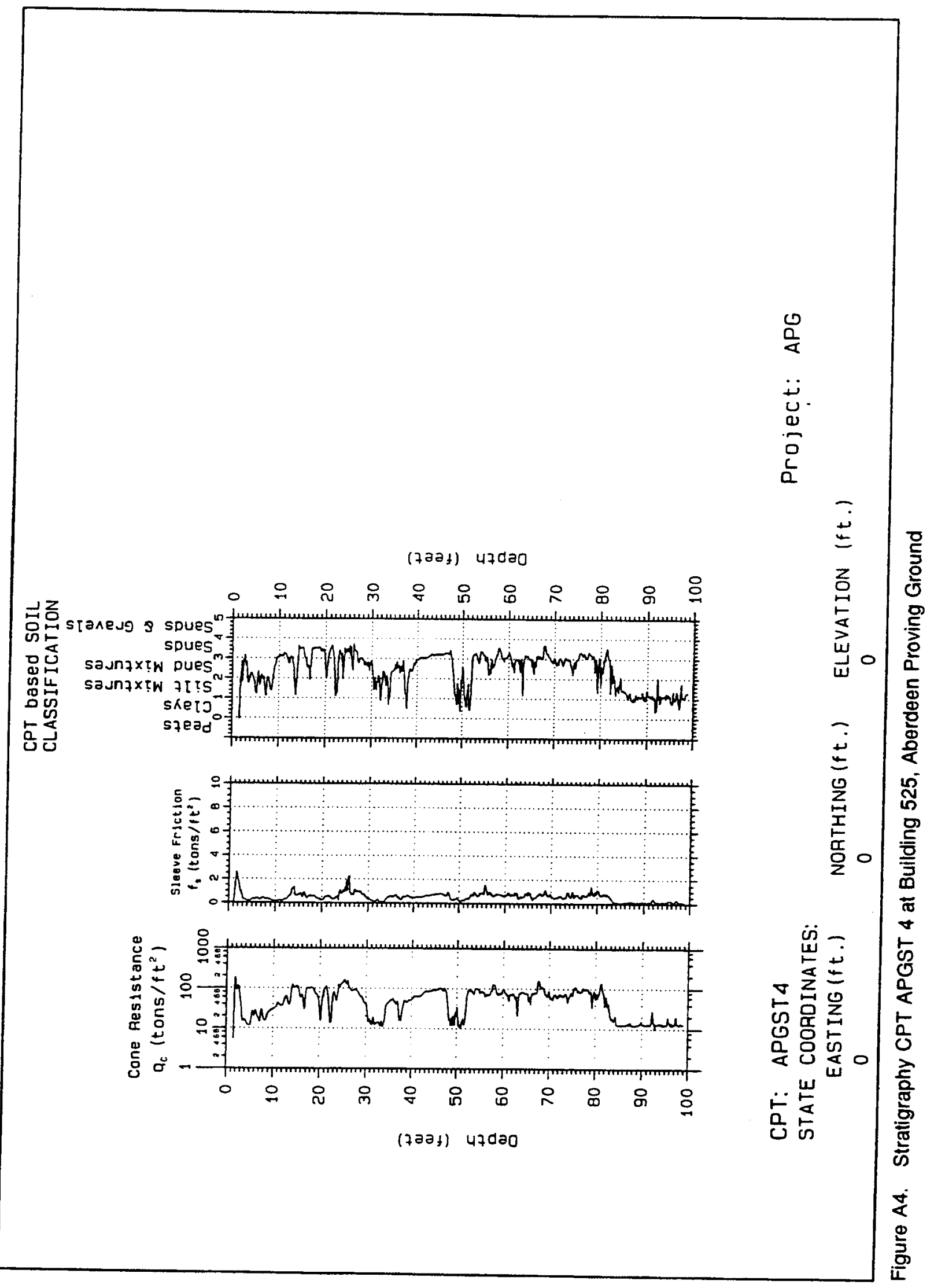




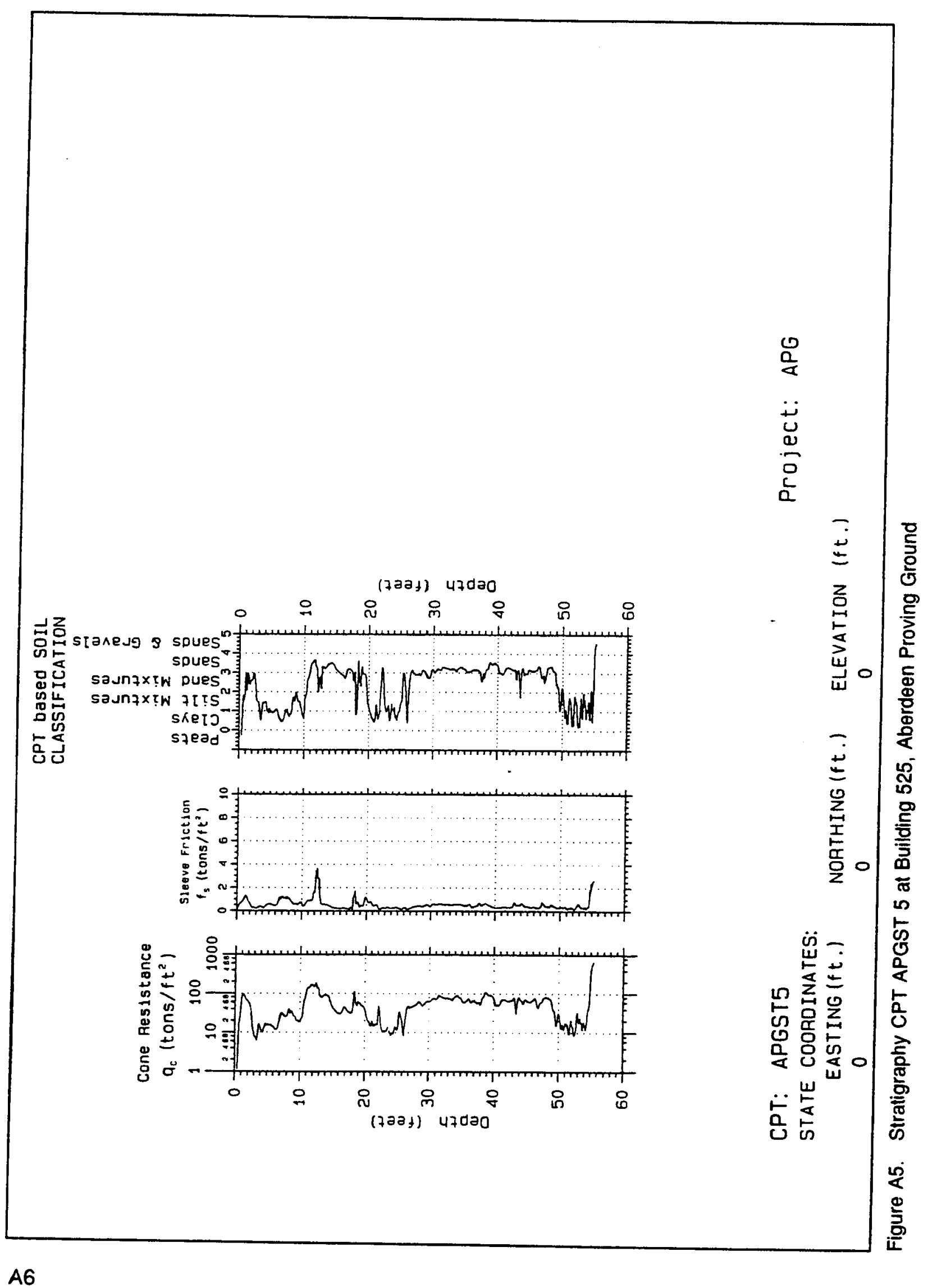




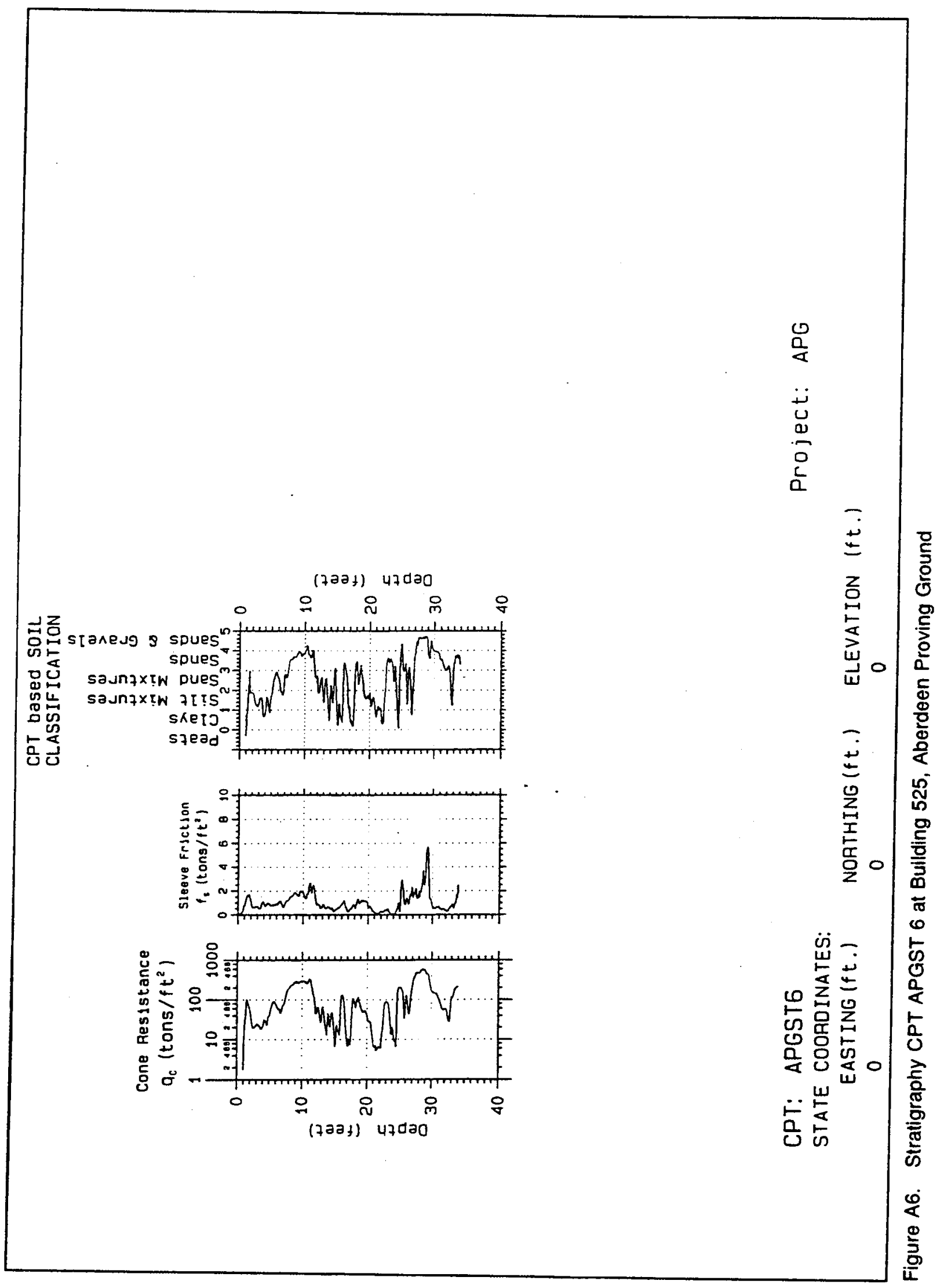


Public reporting burden for this collection of information is estumated to overage 1 hour per rexponse, induding the time for reviewing instructions, searching existing dax a sources. gathering and maintaining the data needed. and completing and reviewing the collection of information. Send comments regarding this burden estimate or ary other aspert of this

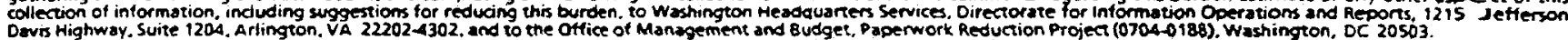

\begin{tabular}{l|l|l|l|} 
1. AGENCY USE ONLY (Leave blank) & 2. REPORT DATE & 3. REPORT TYPE AND DATES COVERED
\end{tabular}

\begin{tabular}{l|l|l}
\hline & September 1997 & Final report
\end{tabular}

4. TITLE AND SUBTITLE
SCAPS Investigation of Chlorinated Volatile Organic

Compounds in Groundwater at Building 525, Aberdeen

Proving Ground Maryland

6. AUTHOR(S)

William M. Davis, Jeff F. Powell,

S. Paul Miller, Stanley M. Swartzel

7. PERFORMING ORGAMIZATION NAME(S) AND ADORESS(ES)

U.S. Army Engineer Waterways Experiment Station

3909 Halls Ferry Road

Vicksburg, MS 39180-6199

8. PERFORMING ORGANIZATION REPORT NUMBER

Technical Report

EL-97-18

9. SPONSORING /MONITORING AGENCY NAME(S) AND ADDRESS(ES)

10. SPONSORING/MONITORING AGENCY REPORT NUMBER

U.S. Army Corps of Engineers

Washington, DC 20314-1000

\section{SUPPLEMENTARY NOTES}

Available from National Technical Information Service, 5285 Port Royal Road, Springfield, VA 22161.

12a. DISTRIBUTION/AVAILABILITY STATEMENT

Approved for public release; distribution is unlimited. 12b. DISTRIBUTION COOE

\section{ABSTRACT (Maximum 200 words)}

Site characterization for subsurface contaminants is time-consuming and costly. The Tri-Service Site Characterization and Analysis Penetrometer System (SCAPS) has been developed to reduce the time and cost required for site characterization. Sensors have been developed for a variety of contaminants of concern to the Department of Defense.

The Hydrosparge Volatile Organic Compound (VOC) groundwater sensing system has been developed and was demonstrated at Aberdeen Proving Ground (APG), MD, in August 1995. The Hydrosparge is capable of accessing groundwater, sparging VOC contaminants in situ, and analyzing the contaminant concentrations using a field portable ion trap mass spectrometer. During the 7-day demonstration at Building 525, APB, a total of 29 SCAPS penetrations were performed: 6 stratigraphic penetrations and 23 Hydrosparge penetrations.

The results obtained with the SCAPS in situ technique were verified by collecting groundwater samples and analysis of the verification samples by U.S. Environmental Protection Agency (EPA) Method 8260. Results of verification sample analyses indicated a strong linear relationship with EPA Methods. The SCAPS Hydrosparge deployment at Building 525, APG, demonstrated the rapid site characterization capabilities of the SCAPS VOC sensor.

\begin{tabular}{|c|c|c|c|}
\hline $\begin{array}{l}\text { 14. SUBJECT TERMS } \\
\text { Groundwater contamination }\end{array}$ & Site characterization & & $\begin{array}{l}\text { 15. NUMBER OF PAGES } \\
36\end{array}$ \\
\hline $\begin{array}{l}\text { Penetrometer } \\
\text { SCAPS }\end{array}$ & $\begin{array}{l}\text { VOC } \\
\text { Volatile organic compo }\end{array}$ & nds & 16. PRICE CODE \\
\hline $\begin{array}{l}\text { 17. SECURITY CLASSIFICATION } \\
\text { OF REPORT } \\
\text { UNCLASSIFIED }\end{array}$ & $\begin{array}{l}\text { 18. SECURITY CLASSIFICATION } \\
\text { OF THIS PAGE } \\
\text { UNCLASSIFIED }\end{array}$ & $\begin{array}{l}\text { 19. SECURITY CLASSIFICATION } \\
\text { OF ABSTRACT }\end{array}$ & 20. LIMITATION OF ABST RACT \\
\hline
\end{tabular}

